\title{
Pengaruh Penggunaan LMS dan Aplikasi Telegram terhadap Aktivitas Belajar
}

\author{
Aan Widiyono* \\ PGSD, FTIK, UNISNU Jepara \\ Jalan Taman Siswa, Pekeng, Tahunan, Jepara, Jawa Tengah 59451, Indonesia \\ *Corresponding Author.e-mail: aan.widiyono@unisnu.ac.id
}

\begin{abstract}
Abstrak
Penelitian ini bertujuan untuk mendeskripsikan pengaruh penggunaan LMS dan aplikasi Telegram terhadap aktivitas belajar mahasiswa. Metode penelitian ini menggunakan pendekatan kuantitatif. Sampel dalam penelitian ini adalah mahasiswa PGSD 3A3 UNISNU Jepara pada Mata Kuliah Teknologi Pendidikan yang berjumlah 28 mahasiswa. Instrumen pengumpulan data menggunakan angket dengan skala Likert pada penggunaan LMS, aplikasi telegram, dan aktivitas belajar yang telah diuji validitas dan reliabilitas sebelumnya. Teknik analisis data menggunakan regresi linier berganda. Hasil analisis data menunjukkan bahwa penggunaan LMS berpengaruh positif dan signifikan terhadap aktivitas belajar dengan signifikansi 0,000; Aplikasi Telegram berpengaruh positif dan signifikan terhadap aktivitas belajar dengan signifikansi 0,000, dan Penggunaan LMS dan aplikasi Telegram secara simultan berpengaruh signifikan terhadap aktivitas belajar sejumlah $90,1 \%$ dengan signifikansi 0,000 . Penelitian ini dapat dijadikan acuan bahwa penggunaan kedua aplikasi tersebut dapat memberikan pengaruh terhadap aktivitas belajar. Sedangkan pada penggunaan LMS lebih memberikan pengaruh terhadap aktivitas belajar dibanding dengan penggunaan aplikasi Telegram.
\end{abstract}

Kata Kunci: learning management system (LMS), aplikasi telegram, aktivitas belajar

\section{The Effect of Using LMS and Telegram on Students' Learning Activities}

\begin{abstract}
This study aims to describe the effect of using LMS and Telegram applications on student learning activities. This research method uses a quantitative approach. The sample in this study were 28 students of PGSD $3 A 3$ UNISNU Jepara in the Educational Technology course. The data collection instrument used a questionnaire with a Likert scale on the use of LMS, Telegram application, and learning activities that had been tested for validity and reliability before. The data analysis technique used multiple linear regression. The results of data analysis indicate that the use of LMS has a positive and significant effect on learning activities with a significance of 0.000; Telegram application has a positive and significant effect on learning activities with a significance of 0.000, and The use of LMS and Telegram application simultaneously have a significant effect on learning activities amounting to $90.1 \%$ with a significance of 0.000 . This research can be used as a reference that the use of these two applications can influence learning activities. Whereas the use of LMS has more influence on learning activities than the use of the Telegram application.
\end{abstract}

Keywords: learning management system (LMS), telegram application, learning activities

How to Cite: Widiyono, A. (2021). Pengaruh penggunaan LMS dan aplikasi telegram terhadap aktivitas belajar. Jurnal Penelitian Ilmu Pendidikan, 14(1), 91-101. doi:https://doi.org/10.21831/jpipfip.v14i1.37857.

Received 15-01-2021; Received in revised from 04-02-2021; Accepted 07-03-2021 
Jurnal Penelitian Ilmu Pendidikan, 14 (1), 2021 - 92
Widiyono

\section{PENDAHULUAN}

Wabah pandemi Covid-19 membuat perubahan semakin cepat dalam tatanan nasional. Kondisi ini membuat sebuah pola tatanan hidup baru yang menyebabkan pengaruh di segala bidang, seperti sosial, ekonomi, dan pendidikan. Pada bidang pendidikan setiap sekolah dari tingkat SD sampai perguruan tinggi diwajibkan melakukan pembelajaran daring (online), tidak terkecuali Universitas Islam Nahdlatul Ulama (UNISNU) Jepara sebagai salah satu PTKIS yang berada di bawah Kementerian Agama. Merespon kebijakan tersebut dengan melakukan penerapan belajar dan bekerja dari rumah berdasarkan Surat Keputusan Rektor pada tanggal 16, 27 maret 2020 dan 8 April 2020 (Widiyono, 2020a). Pembelajaran daring merupakan proses kegiatan pembelajaran yang dilakukan melalui jaringan internet sebagai sarana belajar, kondisi ini menuntut dosen untuk selalu berinovasi dan mengembangkan potensi diri supaya proses pembelajaran dapat berjalan optimal. Penerapan daring secara terus menerus tentunya memberikan pengaruh psikologis bagi dosen dan mahasiswa di UNISNU Jepara, khususnya pada Fakultas Tarbiyah dan Ilmu Keguruan (FTIK) di Program Studi PGSD (Widiyono, 2020a). Hasil penelitian menjelaskan bahwa mahasiswa PGSD menginginkan perkuliahan darling (daring yang dipadukan luring) selama pandemi Covid-19 karena sudah tujuh bulan perkuliahan dilakukan secara daring (Widiyono, 2020). Kondisi ini membuat dilema bagi setiap perguruan tinggi yang mana terdapat masukan dari dosen dan mahasiswa untuk melakukan perkuliahan darling (daring dan luring), namun kondisi ini tidak bisa dilakukan karena adanya surat edaran dari Kemendikbud nomor 36962/ MPK. A/ HK/ 2020 yang menginformasikan bahwa proses perkuliahan yang dilakukan harus secara daring (Pembelajaran Jarak Jauh). Dengan dilakukannya perkuliahan daring secara intensif, UNISNU Jepara melalui Pusat IT memfasilitasi dosen dan mahasiswa dalam menggunakan e-learning berbasis Learning Management System (LMS) yang dapat terkoneksi Spada Indonesia dalam kegiatan perkuliahan. Namun, pada pelaksanaan periode pertama masih belum optimal dikarenakan kurangnya sosialisasi dan pelatihan (bimbingan teknis).

Penerapan Learning Management System (LMS) perlu memberikan kesempatan kepada mahasiswa untuk meningkatkan dan mengembangkan potensinya secara optimal. Selain itu, juga penting diperhatikan metode yang digunakan dapat menstimulan potensi dan bakat sehingga dapat mencakup kebutuhan dan tantangan perkembangan teknologi. Interaksi dan komunikasi dosen dengan mahasiswa pada penggunaan LMS belum optimal (masih terdapat kesenjangan komunikasi) (Simarmata \& Djuanda, 2017). Perbandingan antara LMS, WhatsApp Group, dan Telegram adalah penggunaan aplikasi WhatsApp Group lebih dominan digunakan dibanding dengan penerapan LMS dan Telegram. Kepuasan penggunaan aplikasi WhatsApp Group dalam pembelajaran di masa pandemi Covid-19 diperoleh 63,25\% yang mana hasil tersebut memberikan informasi bahwa para pengajar lebih suka menggunakan aplikasi yang sederhana dan mudah digunakan (Widiyono, 2020b). Meskipun LMS bukan yang paling inovatif dalam beberapa tahun terakhir, tetapi LMS tetap menjadi salah satu sarana belajar yang paling erat pada lembaga pendidikan tinggi (Almrashdeh, Sahari, Zin \& Alsmadi, 2011; Weaver, Spratt \& Nair, 2008; Abazi-Bexheti, Kadriu \& Ahmedi, 2010). Terdapat beberapa tanggapan mahasiswa terkait penerapan LMS seperti koneksi yang tidak stabil dan sering bermasalah, ketika masuk aplikasi LMS masih sering loading lama, server sering down, menu aplikasi bervariasi sehingga membingungkan, dan aturan terkait penerapan LMS yang masih belum disahkan oleh Dekan dan Rektor. Melalui tanya jawab terstruktur dengan beberapa mahasiswa PGSD di kelas 3A3, dihasilkan bahwa para mahasiswa merasa kesulitan dalam menggunakan LMS karena kurangnya sosialisasi dan tutorial yang bisa dijadikan bahan pelatihan. Meskipun terdapat berbagai permasalahan, namun dalam penelitian Sinnun (2017) dihasilkan bahwa penerapan LMS dapat mempermudah kegiatan proses perkulihan karena adanya fitur dan menu yang bervariasi yang dapat memfasilitasi dosen dan mahasiswa.

Learning Management System (LMS) merupakan sistem yang terintegrasi dan komprehensif serta tergolong sebagai platform e-learning. Fitur LMS antara lain, yaitu manajemen proses pembelajaran, manajemen isi pelajaran, administrasi mata pelajaran, chatting, diskusi, serta evaluasi dan ujian yang yang dilakukan secara online (Trivedi, Mohd, \& Sharma, 2013). LMS merupakan sebuah perangkat lunak atau software untuk keperluan administrasi, dokumentasi, pencarian materi, laporan sebuah kegiatan (Ryann K. Ellis, 2010). Istilah global LMS dipakai untuk mengembangkan 
dan mengelola kursus online dan merupakan pusat dari sebagian besar kegiatan e-learning, menyebarkan materi dan sarana komunikasi dan kolaborasi antara dosen dan mahasiswa. LMS merupakan suatu cara yang digunakan untuk mengelola sumber pembelajaran berbasis web. Dengan menggunakan LMS mahasiswa dapat melakukan interaksi dengan mahasiswa lain, mendapat materi perkuliahan, pengiriman tugas, serta informasi lainnya yang berkaitan dengan kegiatan perkuliahan (Listiawan, 2016). Sedangkan platform yang dapat digunakan pembelajaran melalui video conference misalnya Telegram Group, WhatsApp Group, Zoom, Google Meet, Massanger, dan lain-lain.

Kegiatan perkuliahan dapat menerapkan LMS dan Telegram Group. Meskipun kedua aplikasi ini efektif, namun terdapat kendala dalam penerapan LMS. LMS merupakan aplikasi yang mudah bermasalah karena penggunaan yang overload ketika diterapkan untuk seluruh dosen dan mahasiswa di UNISNU Jepara. LMS merupakan sistem baru dari Pusat IT yang diperkenalkan pada dosen dan mahasiswa untuk digunakan dalam kegiatan perkuliahan daring. Sedangkan Telegram Group merupakan aplikasi pengganti apabila LMS mengalami kendala, aplikasi ini dipilih mahasiswa karena penggunaan yang mudah, ringan, dan multiplatform. Telegram juga memiliki fitur yang cukup lengkap dan makin berkembang, sehingga memungkinkan untuk kemudahan dalam aktivitas belajar melalui respon pesan secara langsung (Sastrawangsa, 2017). Melalui fitur-fitur di Telegram Group, dosen dapat dengan mudah menyampaikan informasi mengenai perkuliahan kepada mahasiswa secara tepat dan cepat. Selain dapat memberikan informasi, fitur di Telegram Group dapat mengirimkan sebuah file dan kemudahan mengunduh file tersebut. Hal ini juga bisa membantu dosen dalam menyampaikan materi perkuliahan. Dosen dapat mengunggah materi perkuliahan ke dalam fitur chatting di Telegram Group kemudian mahasiswa dapat mengunduhnya (Gunawan et al, 2018). Seiring aplikasi Telegram Group yang mulai diinstal masyarakat luas dan dipergunakan dalam komunikasi sehari-hari. Aplikasi ini sangat potensial untuk berkembang di kalangan masyarakat. Kelebihan telegram grup menurut Cokrojoyo, Andjarwirawan \& Noertjahyana (2017), adalah terdapat landasan untuk menggunakan Application Programming Interface (API) untuk masyarakat luas. Salah satu API yang disediakan adalah fitur bot. Bot Telegram adalah bot yang saat ini mulai populer dipergunakan sehingga memudahkan dalam pemakaiannya. Bot telegram atau robot yang diprogram dengan berbagai perintah untuk menjalankan serangkaian instruksi yang diberikan oleh pengguna. Telegram bot juga dapat memberikan sebuah layanan berupa peringatan atau pemberitahuan mengenai penerjemahan, pemformatan, searching, dan lainnya. Selain itu, telegram bot dapat terintegrasi dengan berbagai layanan eksternal seperti bot Gmail, bot GIF, bot Wiki, bot music, bot Youtube, dan berbagai layanan eksternal lainnya.

Berbagai aplikasi yang digunakan seperti Learning Management System (LMS) dan Aplikasi Telegram Group dapat memberikan kemudahan dalam interaksi dalam proses pembelajaran. Kegiatan pembelajaran yang baik dapat dilihat dari aktivitas belajar dalam mengikuti pembelajaran. Aktivitas belajar (Wijaya, 2015) adalah interaksi antara individu dengan individu dan individu dengan lingkungan yang dapat membawa perubahan ke arah yang lebih baik. Belajar adalah sebuah aktivitas, tidak ada belajar kalau tidak melakukan aktivitas, kondisi ini memberikan hal penting karena aktivitas merupakan prinsip yang sangat vital di dalam interaksi belajar-mengajar (Am Sardiman, 2011). Segala pengetahuan itu harus diperoleh dengan pengamatan sendiri, pengalaman sendiri, penyelidikan sendiri, dengan bekerja sendiri, dengan fasilitas yang diciptakan sendiri baik secara rohani maupun teknis. Hal ini berarti menunjukkan setiap orang yang belajar harus aktif, tanpa adanya aktivitas maka proses belajar tidak mungkin terjadi. Karena dengan aktivitas belajar keterlibatan mahasiswa dalam proses pembelajaran akan meningkat. Selain aktivitas belajar yang mempengaruhi keberhasilan belajar, kemandirian belajar juga merupakan faktor yang berasal dari diri individu yang mempengaruhi prestasi belajar (Septiyaningsih, 2017, p.).

Pada penelitian sebelumnya, penerapan LMS dan Telegram Group digunakan dalam proses perkuliahan daring di masa pandemi dengan intensitas yang cukup tinggi (Widiyono, 2020b). Penggunaan LMS selama kegiatan perkuliahan dapat dilakukan oleh siapapun (Subiyantoro \& Ismail, 2017). Beberapa penelitian terkait LMS menghasilkan bahwa mahasiswa lebih mandiri dan aktif dalam perkuliahan (Listiawan, 2016). Sedangkan pada penerapan telegram berbasis blended learning sangat membantu dalam pembelajaran dalam menyampaikan materi sehingga memberikan pengalaman belajar yang bermakna (Karyadi, 2018). Dari sudut pandang tersebut, penerapan kedua aplikasi sama-sama efektif dalam proses perkuliahan. Namun, disisi lain perlu dikaji lebih efektif 
mana penggunaan aplikasi Telegram Group dan LMS dalam proses perkuliahan. Untuk itu, penelitian ini lebih berfokus bagaimana penerapan aplikasi Telegram Group dan Learning Management System (LMS) terhadap aktivitas belajar mahasiswa di Prodi PGSD UNISNU Jepara. Dengan demikian, penelitian ini memiliki tujuan supaya aplikasi yang telah digunakan (Telegram Group dan LMS) dapat dikembangkan sesuai kebutuhan dosen dan mahasiswa dalam kegiatan perkuliahan sehingga tercipta perkuliahan yang lebih aktif dan efektif. Selain itu, penelitian ini diharapkan dapat membantu meningkatkan aktivitas belajar mahasiswa dalam perkuliahan daring dengan menerapkan kedua aplikasi tersebut.

\section{METODE}

Penelitian ini merupakan penelitian deskriptif kuantitatif. Subjek penelitian adalah mahasiswa PGSD UNISNU Jepara. Teknik penentuan sampel menggunakan sampel jenuh yang mana semua anggota populasi digunakan menjadi sampel. Untuk sampel dalam penelitian ini berjumlah 28 mahasiswa PGSD 3A3. Terdapat 2 jenis variabel, independen (LMS, Telegram) dan dependen (Aktivitas Belajar Mahasiswa PGSD). Teknik pengumpulan data dan analisis data menggunakan bantuan SPSS 25.

Teknik pengumpulan data menggunakan angket (google form). Pengisian angket oleh responden dilakukan pada bulan November 2020. Uji Instrumen menggunakan validitas data dan reliabilitas data. Tujuan dari uji coba instrumen ini adalah untuk menentukan validitas butir angket dan reliabilitas instrumen. Uji validitas data instrumen dapat dijelaskan bahwa nilai $r$ hitung $>r$ tabel berdasarkan uji signifikan 0.05 , artinya bahwa item-item tersebut diatas valid. Hasil ini dapat dilihat pada tabel 1 uji validitas data.

Tabel 1. Uji Validitas

\begin{tabular}{|c|c|c|c|c|c|c|}
\hline \multirow{2}{*}{ No } & \multirow{2}{*}{ Pernyataan } & \multicolumn{2}{|c|}{ Validitas Telegram } & \multicolumn{2}{|c|}{ Validitas LMS } & \multirow{2}{*}{ Ket } \\
\hline & & $\mathrm{r}_{\text {hitung }}$ & $\mathrm{r}_{\text {tabel }}$ & $\mathrm{r}_{\text {hitung }}$ & $\mathrm{r}_{\text {tabel }}$ & \\
\hline 1 & Kemudahan penggunaan aplikasi & 0,835 & 0,374 & 0,749 & 0,374 & valid \\
\hline 2 & Kenyamanan penggunaan aplikasi & 0,833 & 0,374 & 0,824 & 0,374 & valid \\
\hline 3 & Kemudahan pemutaran video pembelajaran dalam memahami materi & 0,497 & 0,374 & 0,786 & 0,374 & valid \\
\hline 4 & $\begin{array}{l}\text { Kepuasan terhadap kecepatan aplikasi dalam menampilkan data yang } \\
\text { diminta }\end{array}$ & 0,823 & 0,374 & 0,894 & 0,374 & valid \\
\hline 5 & Aplikasi dapat digunakan secara online dan offline & 0,543 & 0,374 & 0,800 & 0,374 & valid \\
\hline 6 & Aturan penyajian materi dalam aplikasi tidak membingungkan & 0,747 & 0,374 & 0,862 & 0,374 & valid \\
\hline
\end{tabular}

Uji reliabilitas diperoleh Cronbach's Alpha 0,776 (Telegram Group) dan 0,899 (LMS), karena nilai Cronbach's Alpha keduanya > 0,60 maka disimpulkan angket pada aplikasi Telegram Group dan LMS dinyatakan reliabel atau konsisten. Hasil ini sesuai dengan Tabel 2 berikut ini:

Tabel 2. Uji Reliabilitas

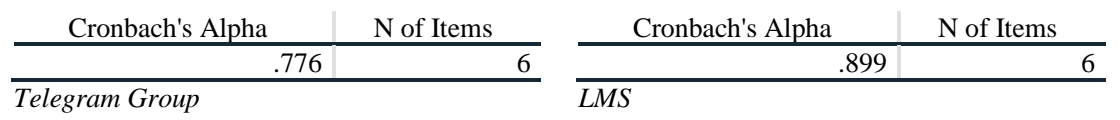

Teknik analisis data menggunakan Uji Prasyarat dan Uji Hipotesis. Uji Prasyarat yang digunakan adalah Uji Normalitas, Uji Multikolinearitas, dan Uji Heteroskedastisitas. Sedangkan pada Uji Hipotesis menggunakan Uji T dan Uji F.

\section{Hasil}

\section{HASIL DAN PEMBAHASAN}

Bagian ini akan mengemukakan hasil penelitian yang telah diperoleh melalui uji prasyarat dan uji hipotesis yang dikemukakan pada beberapa hasil berikut ini. 


\section{Uji Prasyarat}

Uji ini dilakukan untuk mengetahui apakah analisis data dan pengujian hipotesis dapat dilanjutukan atau tidak. Uji prasyarat yang digunakan dalam penelitian ini, melalui:

\section{Uji Normalitas}

Pengujian normalitas yang dilakukan dalam penelitian ini menggunakan uji Kolmogrov Smirnov. Pengujian dilakukan dengan menggunakan Software SPSS 25. Dari hasil perhitungan diperoleh kesimpulan berikut ini: 1) $\mathrm{X} 1(\mathrm{LMS})=0,133$ artinya $>0,05$, maka populasi berdistribusi normal; 2) X2 (Telegram) $=0,140$ artinya > 0,05 maka populasi berdistribusi normal; dan 3) $\mathrm{Y}$ (Aktivitas Belajar) $=0,110$ artinya $>0,05$ maka populasi berdistribusi normal.

Uji Multikolinearitas

Tabel 3. Coefficients ${ }^{a}$

\begin{tabular}{|c|c|c|c|c|c|c|c|c|}
\hline \multirow{2}{*}{\multicolumn{2}{|c|}{ Model }} & \multicolumn{2}{|c|}{$\begin{array}{l}\text { Unstandardized } \\
\text { Coefficients }\end{array}$} & \multirow{2}{*}{$\begin{array}{c}\text { Standardized } \\
\text { Coefficients }\end{array}$} & \multirow[t]{2}{*}{$\mathrm{t}$} & \multirow[t]{2}{*}{ Sig. } & \multicolumn{2}{|c|}{ Collinearity Statistics } \\
\hline & & B & Std. Error & & & & Tolerance & VIF \\
\hline \multirow[t]{3}{*}{1} & (Constant) & 6.384 & 1.710 & & 3.733 & .001 & & \\
\hline & LMS & .426 & .035 & .755 & 12.202 & .000 & .959 & 1.042 \\
\hline & Telegram & .383 & .053 & 448 & 7.243 & .000 & .959 & 1.042 \\
\hline
\end{tabular}

Berdasarkan tabel 3 Coefficients $^{a}$, Nilai Tolerance dan VIF masing-masing variabel $\mathrm{X}_{1}$ dan $\mathrm{X}_{2}$ adalah 0,959 lebih besar 0,10. Sementara, nilai VIF pada variabel $X_{1}$ dan $X_{2}$ adalah $1,042<10$. Maka hasil ini disimpulkan bahwa tidak terjadi multikolonieritas dalam model regresi. Berdasarkan kesimpulan tersebut, dapat dijelaskan bahwa jika terdapat multikolinearitas, maka sebuah variabel yang berkorelasi kuat dengan variabel lainnya di dalam model, kekuatan prediksinya tidak handal dan tidak stabil. Sedangkan jika tidak terjadi multikolinearitas, maka sebuah variabel yang berkorelasi lemah dengan variabel lainnya di dalam model sehingga kekuatan prediksinya handal dan stabil.

Uji Heteroskedastisitas

Tabel 4. Uji Glesjer

\begin{tabular}{clccccc}
\hline & & \multicolumn{2}{c}{ Unstandardized Coefficients } & Standardized Coefficients & $\mathrm{t}$ & Sig. \\
\cline { 2 - 7 } Model & $\mathrm{B}$ & Std. Error & Beta & & \\
\hline 1 & (Constant) & 1.736 & 1.012 & & 1.715 & .099 \\
& LMS & -.021 & .021 & -.200 & -1.000 & .327 \\
& Telegram & -.007 & .031 & -.044 & -.222 & .826 \\
\hline
\end{tabular}

a. Dependent Variable: ABS_RES

Berdasarkan tabel 4 dengan menggunakan uji Glesjer diperoleh nilai signifikansi 0,327 dan 0,826 lebih besar dari 0,05, sehingga disimpulkan bahwa data tidak terjadi masalah heteroskedastisitas. Berdasarkan kesimpulan tersebut, dapat dijelaskan bahwa uji glesjer mengusulkan meregres nilai absolut residual terhadap variabel independen dengan hasil probabilitas dikatakan signifikan jika nilai signifikansinya di atas 5\% (0,05). Jika nilai signifikansi di atas 5\% maka tidak terjadi kesamaan variance sehingga model regresi dalam kategori baik karena dapat menghimpun data yang mewakili berbagai ukuran. Sedangkan, jika nilai signifikansi di bawah 5\% maka terjadi kesamaan variance sehingga terjadi homoskedastisitas yang membentuk model regresi dalam kategori kurang baik sehingga tidak dapat menghimpun data yang mewakili berbagai ukuran

Uji Hipotesis

Uji T

Uji T digunakan dalam menguji pengaruh masing-masing variabel bebas secara sendirisendiri terhadap variabel terikat. Proses yang dilakukan adalah mambandingkan t hitung dengan $t$ tabel. Melalui tabel 3 Coefficients ${ }^{a}$ diperoleh nilai signifikansi Learning Management System (LMS) dan Telegram Group adalah sama yaitu 0,000. Sehingga dapat disimpulkan bahwa pengaruh LMS terhadap aktivitas belajar memiliki nilai signifikansi adalah $0,000<0,05$ maka Ho ditolak dan $\mathrm{H}_{1}$ diterima, variabel $\mathrm{X}_{1}$ (LMS) berpengaruh terhadap $\mathrm{Y}$ (Aktivitas Belajar). Selain itu, pengaruh 
Telegram Group terhadap aktivitas belajar memiliki nilai signifikansi adalah 0,000 $<0,05$ maka $\mathrm{H}_{\mathrm{O}}$ ditolak dan $\mathrm{H}_{2}$ diterima, variabel $\mathrm{X}_{2}$ (Telegram) berpengaruh terhadap Y (Aktivitas Belajar). Hasil dari penerapan Learning Management System (LMS) dan telegram group terhadap aktivitas belajar secara parsial ditemukan bahwa penggunaan kedua aplikasi tersebut sama-sama baik dan efektif dalam kegiatan perkuliahan. Hal ini dibuktikan dengan adanya nilai signifikansi 0,000 kurang dari 0,05. Dengan demikian, kajian tentang Learning Management System (LMS) dan Telegram Group dapat memberikan pengaruh yang berbeda terhadap aktivitas belajar mahasiswa karena dalam penerapannya memiliki perbedaan, seperti penggunaan aplikasi (tingkat kemudahan dan kesulitan), menu dan fasilitas dalam aplikasi, dan koneksi data (kecepatan akses data). Untuk itu, diharapkan penggunaan kedua aplikasi ini dapat benar-benar disesuaikan oleh dosen dan mahasiswa berdasarkan kondisi jaringan dari pengguna, perangkat yang digunakan, dan tingkat kemampuan dari mahasiswa dalam penerapan sebuah teknologi.

Uji F

Uji F pada dasarnya menunjukkan apakah semua variabel independen (bebas) yang dimasukkan dalam model mempunyai pengaruh secara bersama-sama terhadap variabel dependen (terikat). Uji F dapat dilakukan dengan membandingkan F hitung dengan F Tabel. Hasil uji F pada Learning Management System (LMS) dan Telegram Group terhadap aktivitas belajar dapat diamati pada tabel 5 berikut ini.

Tabel 5. Model Summary

\begin{tabular}{|c|c|c|c|c|c|c|c|c|c|}
\hline \multirow[b]{2}{*}{ Model } & \multirow[b]{2}{*}{$\mathrm{R}$} & \multirow[b]{2}{*}{ R Square } & \multirow[b]{2}{*}{$\begin{array}{l}\text { Adjusted R } \\
\text { Square }\end{array}$} & \multirow[b]{2}{*}{$\begin{array}{r}\text { Std. Error of the } \\
\text { Estimate }\end{array}$} & \multicolumn{5}{|c|}{ Change Statistics } \\
\hline & & & & & $\begin{array}{l}\text { R Square } \\
\text { Change }\end{array}$ & F Change & df1 & df2 & $\begin{array}{c}\text { Sig. F } \\
\text { Change }\end{array}$ \\
\hline 1 & $.953^{\mathrm{a}}$ & .908 & .901 & 1.33464 & .908 & 123.549 & 2 & 25 & .000 \\
\hline
\end{tabular}

a. Predictors: (Constant), Telegram, LMS

Berdasarkan hasil output SPSS 25 di atas, dapat kita lihat di mana nilai $\mathrm{F}_{\text {hitung }}$ lebih besar dari nilai $F_{\text {tabel }}(123,549>3,35)$ dengan tingkat signifikan di bawah 0,05 yaitu 0,000 . Berdasarkan cara pengambilan keputusan uji simultan dalam analisis regresi dapat disimpulkan bahwa $\mathrm{H}_{0}$ ditolak dan $\mathrm{H}_{3}$ diterima. Hal ini menunjukan bahwa terdapat pengaruh yang signifikan secara simultan variabel $\mathrm{X}_{1}$ (LMS) dan $\mathrm{X}_{2}$ (Telegram) terhadap Y (Aktivitas Belajar). Hasil Uji R Square 0,908 sama dengan 90,8\%, yang mana dapat disimpulkan bahwa variabel pada Learning Management System (LMS) dan Telegram Group secara simultan berpengaruh terhadap aktivitas belajar mahasiswa sebesar 90,8\%.

Learning Management System (LMS) UNISNU Jepara berpengaruh besar terhadap proses aktivitas belajar. Namun, dalam penerapannya lebih mudah menggunakan Telegram Group dalam kegiatan perkuliahan daring selama Covid-19. Hal ini sesuai pada tabel 6.

Tabel 6. Deskripsi Hasil Angket

\begin{tabular}{|c|c|c|c|c|c|}
\hline No & Pernyataan & LMS & Telegram & Selisih & Ket \\
\hline 1 & Kemudahan penggunaan aplikasi & $61 \%$ & $83 \%$ & $22 \%$ & LMS < Telegram \\
\hline 2 & Kenyamanan penggunaan aplikasi & $63 \%$ & $76 \%$ & $13 \%$ & LMS $<$ Telegram \\
\hline 3 & $\begin{array}{l}\text { Kemudahan pemutaran video pembelajaran dalam } \\
\text { memahami materi }\end{array}$ & $75 \%$ & $87 \%$ & $12 \%$ & LMS $<$ Telegram \\
\hline 4 & $\begin{array}{l}\text { Kepuasan terhadap kecepatan aplikasi dalam } \\
\text { menampilkan data yang diminta }\end{array}$ & $58 \%$ & $76 \%$ & $18 \%$ & LMS $<$ Telegram \\
\hline 5 & Aplikasi dapat digunakan secara online dan offline & $53 \%$ & $67 \%$ & $14 \%$ & LMS $<$ Telegram \\
\hline 6 & $\begin{array}{l}\text { Aturan penyajian materi dalam aplikasi tidak } \\
\text { membingungkan }\end{array}$ & $60 \%$ & $76 \%$ & $16 \%$ & LMS $<$ Telegram \\
\hline
\end{tabular}

Berdasarkan tabel 6 dapat dijelaskan bahwa selisih paling tinggi terkait penggunaan Learning Management System (LMS) dan Telegram Group adalah pada kemudahan penggunaan aplikasi yang selisihnya sejumlah $22 \%$. Jadi kedepan e-learning pada aplikasi belajar melalui LMS dapat mengikuti fitur yang ada di telegram supaya lebih praktis dan mudah digunakan. 
Jurnal Penelitian Ilmu Pendidikan, 14 (1), 2021 - 97

Widiyono

\section{Pembahasan}

Hasil penelitian yang sudah dilakukan ditemukan bahwa terdapat pengaruh LMS terhadap aktivitas belajar. Hasil penelitian ini sesuai dengan penelitian yang dilakukan Utami (2016) yang menunjukkan bahwa penggunaan media e-learning LMS dapat meningkatkan aktivitas belajar siswa. Sedangkan, aktivitas belajar siswa diperoleh indikator mencapai 81,8 \%, yang mana penggunaan LMS memiliki kategori sangat tinggi (Jayusman, \& Shavab, 2020). Hasil lain menjelaskan bahwa mayoritas mahasiswa memberikan tanggapan positif yaitu merasa bahagia ketika ada aplikasi baru yang mampu dijadikan wadah dalam kegiatan proses perkuliahan. Selain itu, mahasiswa sangat tertarik dan memberikan respon positif dalam menggunakan aplikasi LMS selama proses pembelajaran (Sanova, 2018). Sedangkan pada penggunaan pembelajaran berbasis LMS dalam perkuliahan di PGSD telah mendorong mahasiswa untuk lebih mandiri dalam perkuliahan, mengajak mahasiswa berinteraksi secara online (collaborative learning), dan membuat mahasiswa melakukan penelitian (Hardini, 2017). Dengan demikian penggunaan LMS merupakan sistem penyedia sarana belajar. Sehingga perguruan tinggi dapat memanfaatkan LMS untuk keperluan administrasi, dokumentasi, pelaporan kegiatan, pelaksanaan kegiatan pembelajaran, maupun pelaksanaan ujian online. LMS dalam perguruan tinggi berfungsi untuk mengatur tata laksana penyelenggaraan pembelajaran di dalam model e-learning. LMS ini berisi materi-materi dalam kompetensi pedagogik dan profesional yang dibuat dengan kemasan multimedia (teks, animasi, video, sound) dan diberikan sebagai supplemen dan enrichment bagi pengembangan kompetensi pembelajar. Hadirnya LMS membawa harapan lebih baik dari sistem pendidikan yang berjalan saat ini sehingga dapat meningkatkan aktivitas belajar mahasiswa. Namun, di sisi lain penerapan LMS dapat kurang efektif, jika aktivitas pengajar di LMS pasif yang dapat dilihat pada kurangnya partisipasi pengajar di forum diskusi (Kasmanto, 2020).

Berdasarkan hasil uji hipotesis ditemukan bahwa aplikasi Telegram Group berpengaruh terhadap aktivitas belajar. Hasil penelitian ini sesuai dengan penelitian yang dilakukan Karyadi (2018) yang menerangkan bahwa pemanfaatan Telegram Messenger dalam pembelajaran berbasis blended learning sangat membantu dalam pembelajaran, selain dapat membantu dosen untuk menyampaikan materi, siswa juga melakukan aktivitas belajar supaya mendapat berbagai pengalaman belajar. Sedangkan hasil penelitian lain menjelaskan bahwa pemakaian aplikasi Telegram dalam latihan mengerjakan soal IPA dapat meningkatkan hasil belajar dan aktivitas belajar siswa (Septia, 2019). Aplikasi Telegram dapat membuat aktivitas partisipan selama pembelajaran berlangsung aktif, respon partisipan secara umum memiliki tingkat penerimaan baik serta penguasaan konsep partisipan dalam perkuliahan dengan blended learning (Qamar et al., 2018). Penerapan aplikasi telegram dapat membuat mayoritas siswa menganggap Telegram sebagai alat yang berguna untuk pembelajaran dan mampu menumbuhkan sikap positif (A. Abu-Ayfah, 2019; Aghajani \& Adloo, 2018). Dengan demikian, selama pembelajaran berlangsung penguasaan konsep mahasiswa dalam perkuliahan menggunakan aplikasi telegram dapat berjalan dengan baik.

Berdasarkan hasil angket terhadap penerapan aplikasi Telegram Group dan Learning Management System (LMS) ditemukan bahwa penggunaan aplikasi Telegram Group lebih mudah dibandingkan dengan LMS. Pada hasil penelitian lain menjelaskan bahwa sikap siswa terhadap LMS dan tingkat kepuasan mereka tidak memberikan pengaruh yang signifikan terhadap proses pembeajaran (Ashrafi, Zareravasan, Savoji \& Amani, 2020). Hal ini memberikan hasil bahwa terdapat faktor diri dari mahasiswa untuk menumbuhkan ketertarikan terhadap kegiatan pembelajaran selain menggunakan berbagai platform aplikasi. Sedangkan selisih paling rendah pada penerapan Learning Management System (LMS) dan Telegram Group adalah tentang kemudahan pemutaran video pembelajaran dalam memahami materi dengan selisih mencapai $12 \%$. Hasil ini sesuai dengan penelitian Wang et al., (2012) menjelaskan bahwa the scientific-based LMS on the SPADA was effective on the results of the pedagogical material summative learning. LMS could be easily implemented in the Facebook group. Sedangkan pada hasil penelitian lain juga disampaikan bahwa the scientific-based LMS on the SPADA was effective on the results of the pedagogical material summative learning of the participants of Madrasa PPG at the IAIN Salatiga, Indonesia (Saputro \& Susilowati, 2019). Pelaksanaan pembelajaran menggunakan aplikasi Telegram Group untuk latihan mengerjaan soal IPA menunjukkan peningkatan secara bertahap, yakni mengalami peningkatan pada hal-hal yang positif dan mengalami penurunan pada hal-hal yang negatif sesuai dengan angket siswa 
(Septia, 2019, p.47). Selain itu, pemanfaatan Telegram Group dalam pembelajaran berbasis blended learning sangat membantu dalam pembelajaran, selain dapat membantu guru untuk menyampaikan materi, peserta didik mendapatkan pengalaman belajar yang berarti (Karyadi, 2018, p.274). Pada penelitian lain ditemukan bahwa menggunakan media sosial seperti telegram grup dapat sangat efektif dan menjanjikan dalam proses pembelajaran, selain itu telegram grup dapat menjadi media pembelajaran untuk menunjang suatu mata kuliah untuk mencapai tujuan pembelajaran (Alakrash, Razak \& Bustan, 2020; Momani, 2020; Sabry \& Helwa, 2020; Wahyuni, 2018; Xodabande, 2017).

Hasil secara keseluruhan dapat disimpulkan bahwa penggunaan aplikasi telegram Telegram Group lebih diminati oleh para mahasiswa PGSD dibandingkan dengan penggunaan aplikasi LMS. Hasil ini dapat diketahui dari semua instrumen yang menyatakan bahwa Telegram Group masih unggul dalam semua kategori pernyataan yang telah dijawab responden. Hasil ini berbeda dengan hasil penelitian Paulsen (2003) yang menjelaskan bahwa penggunaan LMS bekerja dengan memuaskan di berbagai lembaga pendidikan di seluruh Eropa. Hal ini menunjukkan bahwa kelompok yang diberi strategi belajar blended learning berbantuan telegram lebih unggul dibandingkan kelompok yang diberi strategi belajar konvensional jika ditinjau dari gaya belajar audio. Harapannya, penerapan aplikasi e-learning berbasis Learning Management System (LMS) masih tetap digunakan dipadukan dengan penggunaan aplikasi Telegram Group. Fitur Learning Management System (LMS) supaya dapat segera di-upgrade sehingga pemanfaatannya lebih optimal. Meskipun penerapan aplikasi telegram sangat dominan dibandingkan LMS. Namun aplikasi LMS harus tetap dilanjutkan karena memiliki fitur yang bervariasi untuk penunjang pembelajaran.

Proses perkuliahan di Program Studi PGSD, dapat berjalan efektif jika dilakukan perbaikan pada aplikasi Learning Menegement System (LMS) yang memungkinkan mahasiswa dapat memiliki bahan atau materi pelajaran sendiri yang dapat diunduh secara langsung melalui website. Selain itu, agar prosentase interaksi antara dosen dengan mahasiswa dapat meningkat. Berbagai studi telah dilakukan terkait dengan implementasi LMS pada jenjang pendidikaan seperti Hardini (2017), menjelaskan bahwa LMS berperan penting dalam perkuliahan, karena dengan adanya LMS mahasiswa lebih mudah untuk mendapatkan materi, mengumpulkan tugas, mengecek kegiatan perkuliahan, dan juga dalam mengikuti evaluasi pembelajaran. Adanya peluang penggunaan pembelajaran berbasis LMS dalam perkuliahan di PGSD adalah mendorong mahasiswa untuk lebih mandiri dalam perkuliahan, mengajak mahasiswa berinteraksi secara online (collaborative learning), dan membuat mahasiswa melakukan penelitian dan analisis (research dan analysis). Serta tantangan dan masalah yang dihadapi pengajar dalam menggunakan pembelajaran berbasis LMS di perkuliahan antara lain kurangnya kemampuan dosen dan mahasiswa dalam menggunakan LMS, dan kurangnya fasilitas yang dibutuhkan. Sedangkan hasil penelitian lain ditemukan bahwa LMS sangat potensial efektif digunakan dalam proses pembelajaran (Listiawan, 2016). Penerapan LMS sangat memungkinkan Dosen dan Mahasiswa mengaksesnya di mana saja, kapan saja, dan melalui device apa saja (komputer, laptop, tablet, atau smartphone). LMS dapat menjadi fasilitas sebagai media penyebaran materi perkuliahan, media penyebaran tugas, serta sebagai media forum diskusi (Muhaimin et al., 2021). Selain LMS kegiatan perkuliahan selama pandemi Covid-19 dapat dilakukan menggunakan Edmodo, Quipper, Google Classroom yang dapat diakses oleh siapapun (open course) dan tanpa harus membayar (Subiyantoro \& Ismail, 2017). Platform ini dapat difungsikan sebagai media pembelajaran sekaligus sebagai sumber belajar bagi mahasiswa. Fitur penting dari LMS adalah fitur administrasi, fitur penyampaian bahan ajar, fitur pengujian, fitur penilaian dan fitur komunikasi yang dapat dimanfaatkan bidang pendidikan (Lestari, 2015).

\section{PENUTUP}

Penggunaan Learning Management System (LMS) dan aplikasi Telegram Group secara simultan berpengaruh signifikan terhadap aktivitas belajar sejumlah 90,1\% dengan signifikansi 0,000. Penelitian ini dapat dijadikan acuan bahwa penggunaan Learning Management System (LMS) dan aplikasi Telegram Group dapat memberikan pengaruh terhadap aktivitas belajar. Sedangkan, pada penggunaan Learning Management System (LMS) lebih memberikan pengaruh terhadap aktivitas belajar dibanding dengan penggunaan aplikasi telegram. Selain itu, hasil penelitian ini dapat dijadikan pertimbangan bahwa pelaksanaan perkuliahan harus memberikan kemudahan akses dalam 
penggunaan aplikasi, koneksi jaringan internet, fitur dan menu yang disesuaikan kebutuhan pembelajaran. Meskipun penerapan LMS ketika daring pada periode pertama belum optimal, namun LMS memberikan sebuah perubahan yang positif dengan berbagai penggunaan menu (fitur) yang lebih lengkap dibanding dengan e-learning lama. Untuk itu, diharapkan LMS UNISNU dapat dikembangkan lagi sesuai dengan kebutuhan para Dosen dan Mahasiswa dalam kegiatan perkuliahan.

Dengan hasil penelitian ini, diharapkan UNISNU Jepara melalui UPT Pusat data dan Pengembangan IT dapat mengembangkan Learning Management System (LMS) sesuai dengan kebutuhan dosen dan mahasiswa dengan membuat tutorial sederhana penggunaan LMS yang lebih rinci, memperbaiki menu dan tampilan yang lebih sederhana, dan memperbaiki jaringan supaya lebih stabil. Saran untuk peneliti lain adalah penerapan LMS dalam perkuliahan perlu diteliti dan dikaji ulang, apakah LMS yang dilakukan dimasing-masing universitas sudah efektif ataukah belum. Hal ini dikarenakan aplikasi LMS yang sudah dirancang sesuai kebutuhan dosen dan mahasiswa masih memungkinkan terdapat sebuah kendala sehingga membutuhkan pengembangan sesuai dengan perkembangan teknologi yang ada.

\section{DAFTAR PUSTAKA}

Abazi-Bexheti, L., Kadriu, A., \& Ahmedi, L. (2010). Measurement and assessment of learning management system usage department of communication science and technology. Advanced Educational Technologies, 183-186.

Abu-Ayfah, A. Z. (2019). Telegram app in learning English: EFL students' perceptions. English Language Teaching, 13(1), 51. https://doi.org/10.5539/elt.v13n1p51.

Aghajani, M., \& Adloo, M. (2018). The effect of online cooperative learning on students' writing skills and attitudes through telegram application. International Journal of Instruction, 11(3), 433-448. https://doi.org/10.12973/iji.2018.11330a.

Alakrash, H. M., Razak, N. A., \& Bustan, E. S. (2020). The effectiveness of employing telegram application in teaching vocabulary: A quasai experimental study. Multicultular Education, 6(1), 151-159. https://doi.org/10.5281/zenodo.3905099.

Almrashdeh, I. A., Sahari, N., Zin, N. A. M., \& Alsmadi, M. (2011). Instructor's success measures of learning management system. Proceedings of the 2011 International Conference on Electrical Engineering and Informatics, ICEEI 2011, July. https://doi.org/10.1109/ICEEI.2011.6021516.

Ashrafi, A., Zareravasan, A., Savoji, S. R., \& Amani, M. (2020). Exploring factors influencing students' continuance intention to use the learning management system (LMS): a multiperspective framework. Interactive Learning Environments, $O(0)$, 1-23. https://doi.org/10.1080/10494820.2020.1734028.

Cokrojoyo, A., Andjarwirawan, J., \& Noertjahyana, A. (2017). Pembuatan bot telegram untuk mengambil informasi dan jadwal film menggunakan php. Jurnal Infra, 5(1), 224-227, Program Studi Teknik Informatika http://studentjournal.petra.ac.id/index.php/teknik-informatika/article/view/5163.

Gunawan, L. N., Anjarwirawan, J., \& Handojo, A. (2018). Aplikasi bot telegram untuk media informasi perkuliahan program studi informatika-sistem informasi bisnis universitas kristen petra. Jurnal Infra Petra, 6(1), 921-921. http://www.nature.com/doifinder/10.1038/nri2221.

Hardini, A. T. A. (2017). Pembelajaran berbasis LMS dalam perkuliahan di prodi PGSD: Peran, peluang dan tantangannya. Prosiding Seminar Nasional, 135-144. http://pgsd.umk.ac.id/files/prosiding/2017/16 Agustina UKSW.pdf.

Jayusman, I. \& Shavab, O. A. K. (2020). Studi deskriptif kuantitatif tentang aktivitas belajar mahasiswa dengan meggunakan media pembelajaran edmodo dalam pembelajaran sejarah. Jurnal Artefak, 7(1), 13-20.

Karyadi, B. (2018). Pemanfaatan telegram messenger pada pembelajaran berbasis blended learning di smk geo informatika. Prosiding Sntp, 271-274. http://pkm.uikabogor.ac.id/index.php/SNTP/article/download/271/242.

Kasmanto, R. (2020). Analisis pelatihan online teknis big data menggunakan data logger Moodle. 
Jurnal Penelitian Ilmu Pendidikan, 13(2), 137-146.

Lestari, I. (2015). Evaluasi fungsionalitas learning management system berdasarkan iso/iec. Jurnal Sains, Teknologi Dan Industri, 13(1), 123-129.

Listiawan, T. (2016). Pengembangan learning management system (LMS) di program studi pendidikan matematika stkip pgri Tulungagung. JIPI (Jurnal Ilmiah Penelitian dan Pembelajaran Informatika), 1(01), 14-22. https://doi.org/10.29100/jipi.v1i01.13.

Momani, M. A. M. A. (2020). The effectiveness of social media application "telegram messenger" in improving students' reading skills: A case study of efl learners at Ajloun university college/Jordan. Journal of Language Teaching and Research, 11(3), 373. https://doi.org/10.17507/jltr.1103.05.

Paulsen, M. F. (2003). Experiences with learning management systems in 113 European institutions. Educational Technology \& Society, 6(4), 134-148. https://www.jstor.org/stable/jeductechsoci.6.issue-4.

Qamar, K., \& Riyadi, S (2018). Efektivitas blended learning menggunakan aplikasi telegram. AtTajdid: Jurnal Ilmu Tarbiyah, 7(1), 1-15.

Ellis, R. K. (2009). A field guide to learning management systems. Learning circuits, retrieved from https://web.csulb.edu > web > LMS fieldguide 20091, 12-2-2021, at 13.02.

Sabry, H., \& Helwa, A. A. (2020). Integrating telegram application into digital mind mapping to develop student teachers' EFL critical reading and writing skills by. Journal of Faculty of Education, 2(31), 1-54.

Sanova, A. (2018). Learning management system (LMS) sebagai aplikasi pengembangan materi interaktif pada mata kimia lingkungan dengan metode computer assisted instruction. Jurnal Sains Sosio Humaniora, 2, 227-249.

Saputro, B., \& Susilowati, A. T. (2019). Effectiveness of learning management system (LMS) on innetwork learning system (Spada) based on scientific. Journal for the Education of Gifted Young Scientists, 7(3), 481-498. https://doi.org/10.17478/jegys.606029.

Sardiman, A. (2011). Interaksi dan motivasi belajar mengajar. Depok: Raja Grafindo Persada.

Sastrawangsa, G. (2017). Pemanfaatan telegram bot untuk automatisasi layanan dan informasi mahasiswa dalam konsep smart campus. Konferensi Nasional Sistem \& Informatika, 772776.

Septia, N. I. (2019). Aplikasi telegram (tele-edukasi) dalam pembelajaran ipa di madrasah ibtidaiyah. Premiere: Journal of Islamic Elementary Education, 1(5), 37-48.

Septiyaningsih, S. (2017). Pengaruh aktivitas belajar dan kemandirian belajar terhadap prestasi belajar mahasiswa. Jurnal Pendidikan dan Ekonomi, 6(3), 267-275.

Simarmata, J., \& Djuanda, E. (2017). Rancang bangun model pembelajaran berbasis blended learning management system sebagai knowledge sharing. 2-5. https://doi.org/10.31227/osf.io/bajmh.

Sinnun, A. (2017). Analisis kepuasan pengguna LMS berbasis web. Jurnal Informatika, 4(1), 146154.

Subiyantoro, S., \& Ismail. (2017). Dampak learning management system (LMS) pada performa akademik mahasiswa di perguruan tinggi. Pendidikan \& Pembelajaran, 2(4), 307-314. https://ojs.iptpisurakarta.org/index.php/Edudikara/article/download/63/44/.

Trivedi, R. K., Mohd, N. \& Sharma, R. (2013). Proposed framework for open source based e-learning implementation in Uttarakhand. International Journal of Engineering Research \& Technology, 2(11), 2270-2279.

Utami, I. (2016). Implementasi e-learning menggunakan $\mathrm{cms}$ moodle untuk meningkatkan aktivitas belajar siswa. Jurnal Komputer Terapan, 2(2), 169-178.

Wahyuni, S. (2018). Students' perspectives on using telegram messenger as a learning media. ELTLectura: Jurnal Pendidikan, 5(1), 45-52. http://www.leisaal.org/web/images/stories/revistapdf/vol22n2.pdf\#page $=30$.

Wang, Q., Woo, H. L., Quek, C. L., Yang, Y., \& Liu, M. (2012). Using the facebook group as a learning management system: An exploratory study. British Journal of Educational Technology, 43(3), 428-438. https://doi.org/10.1111/j.1467-8535.2011.01195.x.

Weaver, D., Spratt, C., Nair, C. S. (2008). Academic and student use of a learning management system: Implications for quality. Australasian Journal of Educational Technology, 24(1), 30- 


\section{Jurnal Penelitian Ilmu Pendidikan, 14 (1), 2021 - 101 \\ Widiyono}

41. https://doi.org/10.14742/ajet.1228.

Widiyono, A. (2020a). Efektifitas perkuliahan daring (online) pada mahasiswa pgsd di saat pandemi covid 19. Jurnal Pendidikan, 8(2), 169-177. https://doi.org/10.36232/pendidikan.v8i2.458.

Widiyono, A. (2020b). Penggunaan aplikasi whatsapp group terhadap hasil belajar ipa sd di masa pandemi covid-19. Seminar Nasional Pendidikan Dasar, 5(1). http://proceedings2.upi.edu/index.php/semnaspendas/article/view/1128.

Wijaya, R. (2015). Hubungan kemandirian dengan aktivitas belajar siswa. Jurnal Penelitian Tindakan Bimbingan \& Konseling, 1(3), 40-45.

Xodabande, I. (2017). The effectiveness of social media network telegram in teaching English language pronunciation to Iranian EFL learners. Cogent Education, 4(1). https://doi.org/10.1080/2331186X.2017.1347081. 